UDC 378:37.091.12

DOI 10.33251/2522-1477-2021-9-190-194

MULYK Kateryna,

Candidate of pedagogical sciences, associate professor

at the Department of Western and Oriental Languages and

Methods of their Teaching at the State Institution

"South Ukrainian National Pedagogical University

named after K.D. Ushynsky"

ORCID 0000-0001-6403-3360

\title{
METHODOLOGY OF RESEARCH OF INTEGRATED TEACHING OF PROFESSIONALLY-ORIENTED ENGLISH OF FUTURE SOCIAL WORKERS IN HIGHER EDUCATIONAL INSTITUTIONS
}

The article examines the problem of integrated teaching of professionally-oriented English of future social workers in higher educational institutions. The views of scientists on the methodology of research on this issue are considered. The laws and regularities of integrated teaching of professionally-oriented English of future social workers in higher educational institutions are determined. Prospects for further research of the problem are outlined.

The question of methodological bases of scientific researches was considered in different directions by native and foreign scientists. Any experimental study is primarily a scientific study that uses the provisions of general scientific and pedagogical methodology. Therefore, we consider it logical to determine the basic methodological principles of the study of integrated teaching of professionally-oriented English for future social workers in higher educational institutions.

The purpose of the article is a theoretical analysis of psychological-pedagogical and methodological sources and determination of the main methodological bases of research of integrated teaching of professionally-oriented English of future social workers in higher educational institutions. Our study used the law of unity of theory (pedagogy, methodology, linguistics (English), linguodidactics). This law means that the acquired scientific knowledge, directly or indirectly serves the practice, is implemented in the process of educational or professional activities.

The article presents the views of scientists on the basic concepts of research methodology and identifies the basic laws and patterns of integrated teaching of vocational English to future social workers in higher education. We see prospects for further research in certain principles and approaches to integrated teaching of professionally-oriented English for future social workers in higher educational institutions.

Key words: integrated teaching, professionally-oriented English, social worker, higher education.

Problem statement. Any experimental study is primarily a scientific study that uses the rules of general scientific and pedagogical methodology. Therefore, we consider it logically to determine the basic methodological principles of the study of integrated teaching of professionallyoriented English for future social workers in higher educational institutions.

Analysis of recent research and publications. The question of methodological bases of scientific researches was considered in different directions by native and foreign scientists: pedagogical methodology (S. Goncharenko, V. Zagvyazinsky, A. Bogush, V. Symonenko, I. Bekh, V. Kovalchuk, S. Sysoeva and others); methodology of professional training of future teachers (V. Adolf, I. Zymnya, I. Zyazyun, H. Kuzmina, V. Lozova, A. Rean, O. Savchenko, V. Slastyonin, S. Skvortsova, A. Khutorsky and others); methodology of foreign language training of students (G. Kitaygorodskaya, O. Tarnopolsky, R. Ellis, I. Nation, N. Schmitt, W. Widdowson and others).

The purpose of the article is a theoretical analysis of psycho-pedagogical and methodological sources and determination of the main methodological bases of research of integrated teaching of professionally-oriented English of future social workers in higher educational institutions. 
Let's find out the definition of the concept of "methodology". "Methodology" (from the Greek) means the doctrine of methods or theory of methods; the doctrine of the scientific method of cognition; a set of cognitive tools, methods, techniques used in a particular science; branch of knowledge that studies the essense, background and principles of organization of cognitive and transformational activities. In essence, this is the basis of knowledge and transformation of reality [7, p. 68].

Methodology is a type of rational-reflexive consciousness aimed at studying, improving and constructing methods. The concept of "methodology" has two main meanings: first, it is a system of certain rules, principles and operations applied in a particular field of activity (in science, politics, art, etc.); secondly, it is the doctrine of this system, the general theory of the method [8, p. 84]. "One of the forms of self-knowledge and self-awareness. The methodology determines the essence of scientific activity and its relationship with other areas, its practical, social and cultural implementation" [3, p. 23].

General scientific methodology develops universal principles, means and forms of scientific knowledge that relate, at least potentially, not to any particular science, but to a wide range of sciences, while remaining, in contrast to philosophical methodology, within the actual scientific knowledge, without expanding to general worldview level [9, p. 145].

In pedagogical research, scientists focus on the methodology of pedagogy. Thus, S. Goncharenko defines the methodology of pedagogy as a system of knowledge about the structure of pedagogical theory, principles of approach and ways of acquiring knowledge that reflect pedagogical reality, as well as a system of activities to obtain such knowledge and justify programs, logic, and as a doctrine of this system. The methodology of pedagogy includes the following provisions: the doctrine of the structure and functions of pedagogical knowledge; initial, key, fundamental pedagogical positions (theories, concepts, hypotheses), which have a general scientific meaning; doctrine of logic and methods of pedagogical research; about ways to use the acquired knowledge to improve practice [1].

A particularly important role in the development of methodology and theory of pedagogy is played by the reasonable, balanced use of the achievements of other sciences: philosophy, synergetics, sociology, psychology, and so on. This helps to understand better, explain more accurately and predict the development of certain pedagogical processes, to optimize the teaching and education of the younger generation [1].

S. Goncharenko pointed that the development of pedagogy focused on the past and focuses today on the generalization of practical experience, the most significant pedagogical systems were created on an experimental-theoretical basis. The connection between theory and practice is the cornerstone of scientific methodology. Instead, the nature of the connection between theory and practice is changing, this should be taken into account [1, p. 199].

The methodology of organizing pedagogical research involves focusing on the following methodological positions: laws, patterns, principles, approaches. We characterize the laws and patterns.

Laws and regularities are the basis of the pedagogical system that combines pedagogical theory and pedagogical practice. S. Goncharenko emphasizes that without the laws science does not exist. Knowledge of pedagogical laws helps the teacher to find answers to key questions of education and practice. [1, p. 188]

First of all, let's find out the essence of the term "law". According to the terminological sources, "law" is a multidimensional concept, such as: "a universally binding rule established by the highest body of state power, which has the highest legal force; generally accepted, established rule of coexistence, norm of behaviour; basic rule of conduct in any field of human activity [4, 67]. Thus, depending on the field of activity, the laws are divided into dialectical (laws of development), scientific, pedagogical. Dialectical (philosophical) laws include: the law of unity of struggle and opposites; the law of transition of quantitative changes into qualitative ones; the law of development.

Scientific law is interpreted as established relationships of phenomena, the detection of which allows to describe, explain and predict certain phenomena (results) of reality [9, p. 145]; "Objective, 
necessary, relatively stable connection of phenomena (relations), which determines their necessary development, and the reflection of this connection in theory - the scientific law" [1, p. 27].

S. Honcharenko singles out that pedagogical law, which is as a component of the logical structure of pedagogical science, reflecting the objective, internal, essential and, accordingly, established connections of pedagogical phenomena; contributes to the scientific management of educational activities, predicting the results of a particular type of pedagogical activity [2, p. 16-29].

According to S. Honcharenko, pedagogical laws include the following: the law of interrelation of creative self-realization of a student and educational environment; the law of unity of theory and practice; the law of active activity, etc.

The most important features of the law are necessity, universality, recurrence and invariance [1, p. 27].

The laws of pedagogy development are objective, essential, stable, recurring connections of pedagogical science with its external and internal factors [6, p. 22].

V. Zagvyazinsky singles out the following pedagogical laws:

- the law of social conditionality of goals, content and methods of teaching;

- the law of developmental and educational impact of education on students;

- the law of conditionality of learning outcomes by the nature of activities and communication of students;

- the law of integrity and unity of the pedagogical process;

- the law of interconnection and unity of theory and practice in teaching;

- the law of interconnection and interdependence of individual, group and collective educational activity [3, p. 87].

The study used the law of unity of theory (pedagogy, methodology, linguistics (English), linguodidactics). This law means that the acquired scientific knowledge, directly or indirectly serves the practice and it is implemented in the process of educational or professional activities.

The repetition of laws in the pedagogical process in educational and scientific activities, which leads to a positive result is a regularity. Regularities reflect the causal nature of the activity and its outcome.

Regularities of learning (didactic) - objective, established and significant links in the educational process, which determine its effectiveness: the focus of learning to solve problems of comprehensive and harmonious development of the student's personality; the content of education naturally depends on its tasks, which reflect the needs of society, the level and logic of science development, real studying opportunities and external learning conditions; the dependence of the studying process on the learning opportunities of students (external and internal), which reflect the level of development of intellectual, emotional and volitional spheres of personality, level of knowledge and skills, learning skills, attitude to studying, physical condition and ability to work; active nature of studying; interdependence of educational and cognitive activity of the student and the level of development of his motivational sphere; ensuring the success and achievements of students in the studying process; methods, forms and means of teaching naturally depend on its tasks and content; the interconnection of all components of the learning process naturally provides strong, conscious and effective results of learning, development and education [Goncharenko, 2011: 131].

V. Kremen in defining the concept of "pedagogical regularity" prefers the objectivity of existing, permanent features of the educational process as a whole and considers an indicator of pedagogical regularity the relationship between educational methods and results, between the complexity of educational material and the quality of its assimilation [Kremen, 2005: 369].

Regularities of vocational training are formed under the influence of a set of different sciences: philosophy, sociology, psychology, physiology, and others. The methodological regularities reflect a complex combination of data from all sciences, as a result of which the pedagogical process is studied in all connections and relations.

Scientists (Yu. Babansky, I. Lerner, M. Skatkin, A. Khutorskaya, L. Vygotsky, P. Halperin, etc.) divide the regularities of learning into external and internal. The first - characterize the 
dependence of studying on social processes and conditions: socio-economic, political situation, level of culture, social needs and level of education. The internal links include the components of the pedagogical process: goals, content, methods, tools, forms.

Thus, "pedagogical regularity" is the fact of the existence of objective, established links between the phenomena of the pedagogical process, the reflection of the law in specific conditions.

The leading patterns in the organization of experimental research of integrated training of professionally-oriented English future social workers in the process of professional training were identified as follows:

- integrated learning of professionally-oriented English will be more effective if you provide a positive motivation for the process of learning English. Educational and speech activity of students will be more effective if they have formed the appropriate motivation for integrated learning of English of a professional orientation;

- regularity of synergetic strengthening of results of experimental training, the result of training will be more effective if the teacher is not limited in various techniques and technologies; semantic, personal (character of the teacher) and emotional factors;

- scientific substantiation of forms, methods, receptions and own behaviour (actions) of the teacher who carries out training. The more specific methods influences integrated studying of professionally-oriented English of future social workers will be selected in the experiment, the more effective the results of the experiment will be;

- determined connections between the processes of studying, education and personal development. Taking into account this pattern in the process of integrated teaching of professional English of future social workers involves the use of such teaching methods that affect the formation of their general and English culture, taking into account the existing level of personal development of the future specialist;

- effective studying of professionally-oriented English depends on the relationship of the components of the process of integrated teaching: the goals and content of the pedagogical process, the structure of foreign language material, methods and tools of teaching.

Conclusions and prospects for further research. The article presents the views of scientists on the basic concepts of research methodology and identifies the basic laws and patterns of integrated teaching of professionally-oriented English of future social workers in higher educational institutions. We see the prospects for further research in certain principles and approaches of integrated teaching of professionally-oriented English of future social workers in higher education institutions.

\section{References}

1. Honcharenko, S.U. (2012). Pedahohichni zakony, zakonomirnosti, pryntsypy. Suchasne tlumachennia [Pedagogical laws, patterns, principles. Modern interpretation]. Rivne: Volynski oberehy. [in Ukrainian].

2. Honcharenko, S.U., Pasternak, N.V. (1998). Problema pidvyshchennia teoretychnoho rivnia osvity [The problem of raising the theoretical level of education. Pedagogy. Psychoogia]. Pedahohika. Psykhoohiia. [in Ukrainian].

3. Zahviazynskyi, V., Atakhov, R. (2003). Metodolohyia y metodi psykholohopedahohycheskoho yssledovanyia [Methodology and methods of psychological and pedagogical research]. Moskva. Yzdat. Tsentr "Akademyia". [in Russian].

4. Korotkyi slovnyk aktualnykh pedahohichnykh terminiv (2003). [A short dictionary of relevant pedagogical terms] / upor. N.M. Flehontova. Kyiv: KNUTD [in Ukrainian].

5. Kremen, V.H. (2005). Osvita i nauka v Ukraini - innovatsiini aspekty. Stratehiia. Realizatsiia. Rezultaty [Education and science in Ukraine - innovative aspects. Strategy. Realization. Results]. Kyiv. Hramota. [in Ukrainian].

6. Lerner, Y.Ia. (1971). Protsess obuchenyia y eho zakonomernosty [The learning process and its patterns]. Moskva. Visshaia shkola. [in Russian]. 
7. Sysoieva, S.O. (2013). Metodolohiia naukovo-pedahohichnykh doslidzhen: Pidruchnyk [Methodology of scientific and pedagogical research]. Rivne: Volynski oberehys. [in Ukrainian].

8. Nikolaieva, S.Yu. (1998). Problemy suchasnoi metodyky vykladannia inozemnykh mov [Problems of modern methods of teaching foreign languages]. Kyiv. [in Ukrainian].

9. Shapar, V.B. (2007). Suchasnyi tlumachnyi psykholohichnyi slovnyk [Modern explanatory psychological dictionary]. [in Ukrainian].

\section{Список використаних джерел}

1. Гончаренко С. У. Педагогічні закони, закономірності, принципи. Сучасне тлумачення. Рівне: Волинські обереги, 2012. С. 188-189

2. Гончаренко С. У., Пастернак Н. В. Проблема підвищення теоретичного рівня освіти. Педагогіка. Психоогія. 1998. №2. С.16-29.

3. Загвязинський В., Атахов Р. Методология и методы психологопедагогического исследования. Москва. Издат. Центр «Академия», 2003. С. 199.

4. Короткий словник актуальних педагогічних термінів / упор. Н.М. Флегонтова. Київ: КНУТД, 2013. 55 с.

5. Кремень В. Г. Освіта і наука в Україні - інноваційні аспекти. Стратегія. Реалізація. Результати. Київ. Грамота, 2005. 448 с.

6. Лернер И. Я. Процесс обучения и его закономерности. Москва. Высшая школа, $1971.294 \mathrm{c}$.

7. Сисоєва С. О. Методологія науково-педагогічних досліджень: Підручник. Рівне: Волинські обереги, 2013. 360 с.

8. Ніколаєва С. Ю. Проблеми сучасної методики викладання іноземних мов. Київ. $1998.232 \mathrm{c}$.

9. Шапар В. Б. Сучасний тлумачний психологічний словник. Харків. Прапор, 2007. $640 \mathrm{c}$.

МУЛИК Катерина Олександрівна, кандидат педагогічних наук, доцент кафедри західних і східних мов та методики їх навчання Державний заклад «Південноукраїнський національний університет ім. К.Д. Ушинського».

\section{МЕТОДОЛОГІЯ ДОСЛІДЖЕННЯ ІНТЕГРОВАНОГО НАВЧАННЯ ПРОФЕСІЙНО-СПРЯМОВАНОЇ АНГЛІЙСЬКОЇ МОВИ МАЙБУТНІХ СОЦІАЛЬНИХ ПРАЦІВНИКІВ У ЗАКЛАДАХ ВИЩОЇ ОСВІТИ}

Анотація: У статті досліджено проблему інтегрованого навчання професійноспрямованої англійської мови майбутніх сочіальних працівників у закладах вищої освіти. Розглянуто погляди вчених щзодо методології дослідження означеного питання. Визначено закони та закономірності інтегрованого навчання професійно-спрямованої англійської мови майбутніх сочіальних працівників у закладах вищої освіти. Окреслено перспективи подальшого дослідження проблеми.

Ключові слова: інтегроване навчання, професійно-спрямована англійської мова, сочіальний пращівник, вища освіта. 